\title{
GLL
}

$00=0$ Geomatics, Landmanagement and Landscape No. $4 \cdot 2019,137-144$

\section{PARSONAGE GARDENS - ATTEMPTED RECREATION OF HISTORIC FUNCTIONAL AND SPATIAL LAYOUTS}

\author{
Magdalena Wilkosz-Mamcarczyk, Barbara Olczak
}

\begin{abstract}
Summary
The article is devoted to gardens that were once the property of parsons - in this article, defined as parsonage gardens. They were part of church garden compounds, however, compared to other forms and projects of sacred greenery, they without a doubt attract much less attention. This translates into the fact that this particular term is not used in the literature of the subject, despite the fact that examples of such forms of green spaces can be found in Poland. In the article, we attempt to present parsonage gardens as having both utility and decorative functions, and representing a high degree of harmonization between man-made greenery and the surrounding natural and cultural landscape. The study analysed the shape and layout of such gardens, and their functional and spatial program against the background of the current status of three selected objects from southern Poland, each in a different state of preservation.
\end{abstract}

\section{Keywords}

parsonage gardens $\bullet$ church gardens $\bullet$ utility gardens

\section{Introduction}

Gardens accompanying parsonages constitute one of the examples of developing utility-function and decorative gardens near religious buildings. The very concept of "parsonage garden" as a description of the projects of arranged sacred greenery was appreciated by great Polish artists, and can be found, among others, in the paintings of Julian Fałat (Garden at the parsonage) or Adam Chmielowski (Abandoned parsonage), as well as international artists, including Vincent van Gogh, who created a series of paintings dedicated to parsonage gardens in Nuenen in the Netherlands. In scientific literature it is difficult to come across the concept of a "parsonage garden". Many existing definitions and terms refer to monastery gardens [Ciołek and Bogdanowski 1978, Majdecki 1978] or church gardens [Borcz and Czechowicz 2003] instead.

When trying to define the concept of parsonage garden, one can venture an opinion that this should be done in a reference to the monastery garden. The duties of the parson, who in a sense was the landlord or the keeper of the land owned by the church, included caring for the garden, as well as cultivating the land or grazing animals 
therein. This work resembled that of the monks who, like priests, enjoyed the yield of their crops.

The parsonage garden - together with the church itself, the church gardens and the cemetery - typically formed sacred compounds, harmoniously incorporated both in the village landscape and in the surrounding open landscape. For the most part, they were utility gardens, which included vegetable gardens, herbariums, ponds, orchards and arable fields. Their functioning was subordinated to the needs of the priest, the parson, or the vicar, and the service personnel responsible for maintaining the church and the gardens. In the gardens, buildings serving the parson and other residents were located, such as the parsonage, the vicarage, and outbuildings such as barns, coach houses, or pigsty. Parsonage gardens typically included decorative gardens. The composition and shape of the gardens depended on the terrain, and their form was also influenced by their distance from the church. Usually, the layout prevails, in which the outline of parsonage buildings forms a quadrangle [Hani 1994, Kobielus 1997], inside which there is usually a flower garden and/or a vegetable garden - for instance, this is the case in Marcyporęba. Surrounding the buildings, there are orchards, a pond, and arable fields. In some church and garden compounds, the compositional axis is visible between the church and parsonage buildings - for instance, in the village of Kamien. The size of the gardens depended on the amount of land owned by the church in the given village. It happened at times that the utility areas were expanded to include lands donated to the church. Parsonage gardens were typically semi-open in their character. Due to their location in the focal point of the village, they were often used as a meeting place for its residents.

\section{Material and method}

The article is of a review nature; it analyses selected parsonage gardens that have been preserved either in full or in fragments only. Landscape observations were made using the in situ method, partly supported by the available literature on the subject and accounts of the residents, supplemented with photographic documentation. The present study applies the observation method, which is one of the oldest research methods, consisting in recording specific facts and juxtaposing them, in order to reveal their mutual links and correlations. The collected data are interpreted as phenomena affecting the elements and the processes of a given system, or a specific organizational structure. The application of this method makes it possible to narrow down the issues in the stated research topic. As a complement, the method of individual case studies was used, which included, among other things, examining a specific phenomenon or a process related thereto [Apanowicz 2002, Poskrobko 2012]. The gardens in question are located in three different districts (poviats): Wadowice (wadowicki) district - in the village of Marcyporęba, Krakow (krakowski) district - in the village of Kamien, and Bielsko (bielski) district - in the village of Bujaków (Fig. 1). They differ in many respects: in the degree of preservation of their historical layouts, in their size, and in their contemporary use. 


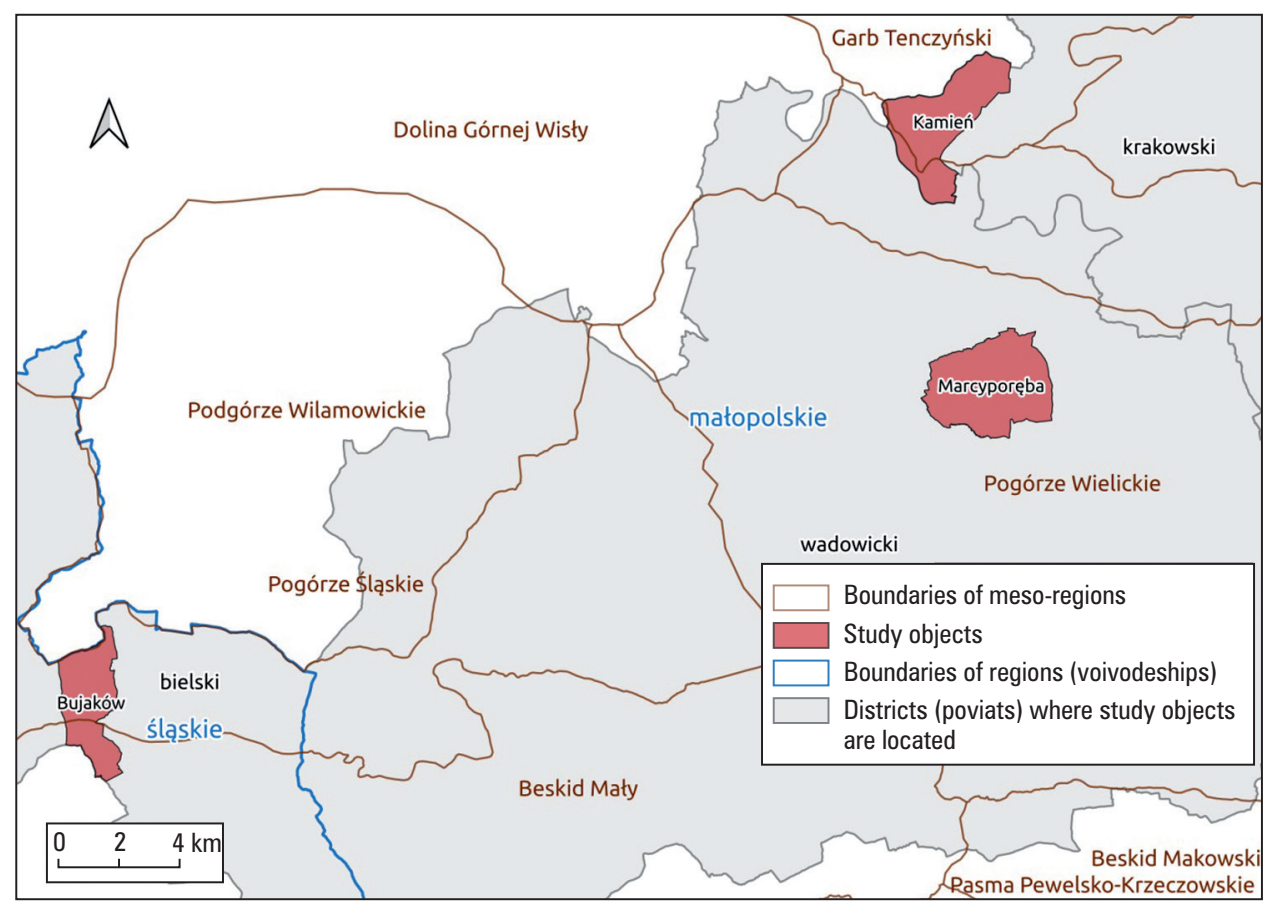

Source: developed by B. Olczak and M. Wilkosz-Mamcarczyk

Fig. 1. Location of the studied areas in relation to meso-regions and administrative divisions

Due to the availability of historical materials, and the surviving outlines of some garden compositions in the field, most of the work is devoted to the garden project in Marcyporęba. This example was treated as a starting-point and model for the determination of a typological group of parsonage gardens, hitherto not defined in the history of garden art. The remaining contributions exist only in the form of photographic documentation, coupled with a "sketchy" description of their contemporary state of preservation and their current function.

\section{Marcyporęba}

Marcyporęba is a village in the Małopolska region (voivodeship), located in the Wadowice district, about $15 \mathrm{~km}$ away from Wadowice (see Fig. 1). The village is located in the western part of the Pogórze Wielickie [Zinkow 2000]. The village boasts a historic church of St. Martin, dating to the seventeenth century, which is featured in the Wooden Architecture Route [Kucharczyk 2002, 2013]. The parsonage garden associated with the functioning of the church in Marcyporęba existed until the 1970s. Currently, only one of the buildings remains, which was once part of the farm facilities belonging to the parish, as well as some of the fruit trees. Together with 
the church garden, the parsonage gardens in this particular complex formed a garden project of designed greenery, spanning over an area of more than one hectare. The central part consisted of a wooden church with surrounding old linden trees. The garden, referred to simply as the church garden, had been established within the bounds of the church cemetery, in the immediate vicinity of the church [Siewniak and Mitkowska 1998]. On the southern side, there was a parsonage garden with buildings: a parsonage, a vicarage, a bakery, servants' quarters, barns, and a coach house. In the middle, there was a courtyard, a vegetable garden and a decorative flowerbed. Below the buildings, to the south-west, there was one of the orchards where fruit trees were grown, including apple, pear and plum trees. In the orchard there was a gazebo, surrounded by larches and chestnut trees, serving as a place of rest for the priest, as well as an apiary, which initially consisted of twelve, and later eight beehives. A fish pond was also located on the west side. The second orchard, with younger trees, was located to the east, near the cemetery. To this day, there are remains of old fruit trees. There was a square in front of the church, colloquially called "targówka" (the marketplace), where important church ceremonies and residents' meetings were held. Chestnut trees grew on the square, most likely planted in such as way as to emphasize the entrance to the temple. Particularly valuable information on the parsonage garden is provided by the contents of a perfectly preserved parish chronicle, supplemented with entries from subsequent parish priests.
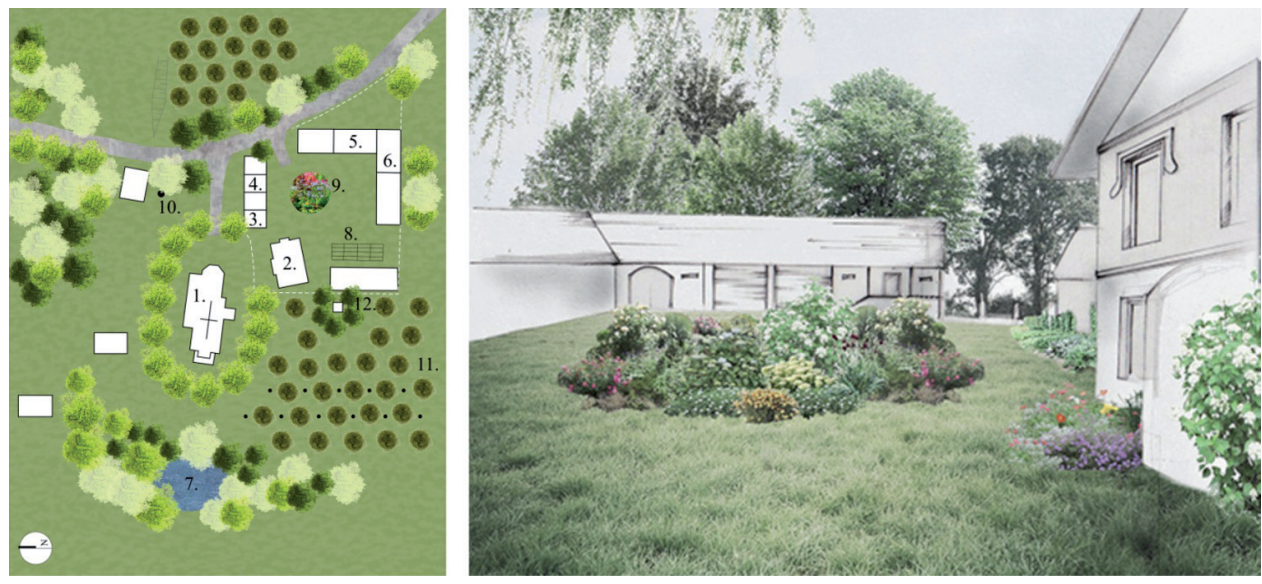

Source: compiled by M. Wilkosz-Mamcarczyk based on an oral account from a resident of Marcyporęba (J. Gramatyka) and the Parish Chronicle (M. Wilkosz-Mamcarczyk)

Fig. 2. Probable layout of the parsonage garden in Marcyporęba. 2.1. Plan: 1. Church; 2. Parsonage; 3. Vicarage; 4. Servants' quarters; 5 . Barn; 6. Coach house; 7. Pond; 8. Vegetable garden; 9. Flower garden; 10. Well; 11. Fruit orchard; 12. Gazebo. Visualization of the former development of the area around the church; 2.2. View of the flower garden, with parsonage on the right, and outbuildings in the background - presumed appearance 
The assembled information, supplemented with interviews that we have conducted with village residents who remember such layout of buildings and gardens, allowed us to approximate the placement of buildings around the church. On that same basis, we also managed to establish what tree species had been planted over the centuries. Currently, a part of the former parsonage garden has a car park located on the roadside, and a new parsonage has been built on the site of the former building. The boundaries of the former orchards are getting increasingly blurred, and most of the trees had been cut down. The ones that survive are very old. There were no beehives preserved, and only entries in the parish records remind us that the pond and the gazebo ever existed in this location. Only the wooden church has survived to this day in essentially unchanged condition, and as such it remains the dominant feature of the village (Fig. 2).

\section{Kamień}

Kamien is a village in the Małopolska region, located in the Kraków district, in Czernichów municipality (see Fig. 1). The compound of the parish church of The Protection of the Mother of God in Kamień, together with a brick parsonage, dates to the early twentieth century. There are practically no traces left of the parsonage gardens in Kamien. Only the fact that there is this huge, fenced-off space suggests the size of the former garden. Only farm buildings from the eighteenth and nineteenth centuries survived to this day (Fig. 3.1 and 3.7), including a brick granary from the turn of the seventeenth and eighteenth centuries (Fig. 3.5 and 3.6), currently used as a small Regional Museum, and a wooden eighteenth-century well (Fig. 3.2). The grandeur of the former garden can be surmised from the enormous, ancient linden trees, which are more than three hundred years old (Fig. 3.4 and 3.8). Unfortunately, no fruit trees have survived. They were cut down at the beginning of the twenty-first century. The garden area is neglected, covered with volunteer (self-seeding) plants and grass. Only in the front part there are traces of the former Italian garden, and this part of the greenery is kept in fairly good condition (Fig. 3).
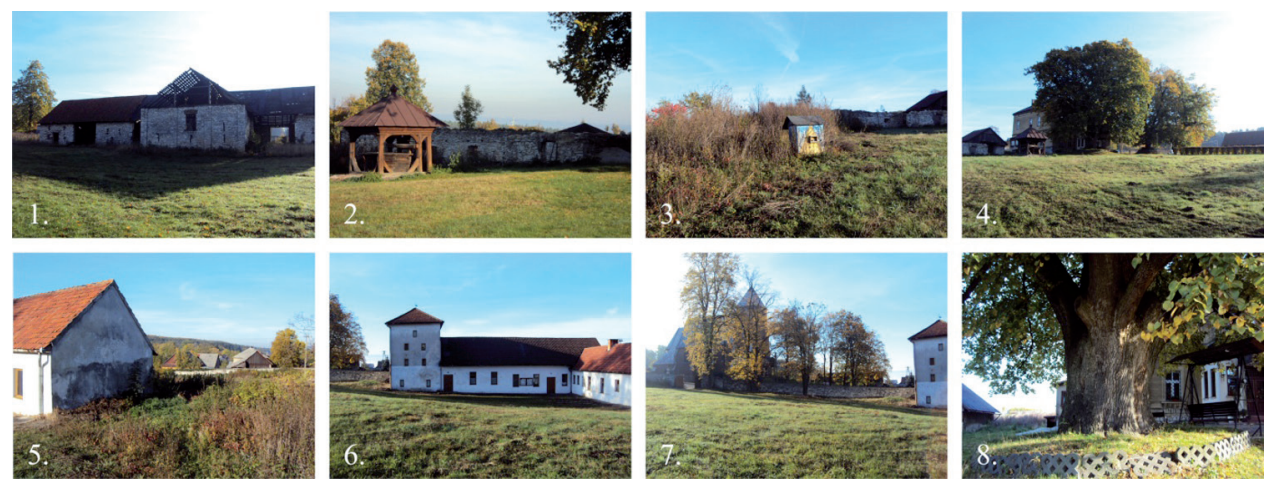

Photo by M. Wilkosz-Mamcarczyk, 2012

Fig. 3. Remains of the parsonage garden in Kamień 


\section{Bujaków}

Bujaków is a village in the Śląsk region (śląskie voivodship), one of the five villages within the administrative boundaries of the city of Mikołów (see Fig. 1). A historic church from the year 1500 is located in the village. In 1976, on the initiative of priest Jerzy Kempe, then the parson at the Sanctuary of the Mother of God, the Protectress of Nature, botanical garden was established in parsonage gardens [Parish in Bujaków]. It incorporated a historic parsonage from 1820 (Fig. 4.4) and a convent of the Little Servant Sisters of Immaculate Conception. Various parts of the garden were assigned different functions. There is a recreation and leisure part with a place where meetings take place, along with an extensive pond with an islet (Fig. 4.1-4.3). There is also herb garden and an apiary (Fig. 4.6). The garden is rich in many attractions for visitors, including decorative birds, such as peacocks and hens (Fig. 4.8), as well as elements of historic heritage, such as the penitential cross from the seventeenth century. Statues of saints were placed in the garden (Fig. 4.2), as well as small shrines (Fig. 4.7). Currently, the garden serves parishioners and visitors to the place, and is not only functional, i.e. serving utilitarian purpose, but in fact it is used primarily as a decorative garden (Fig. 5).
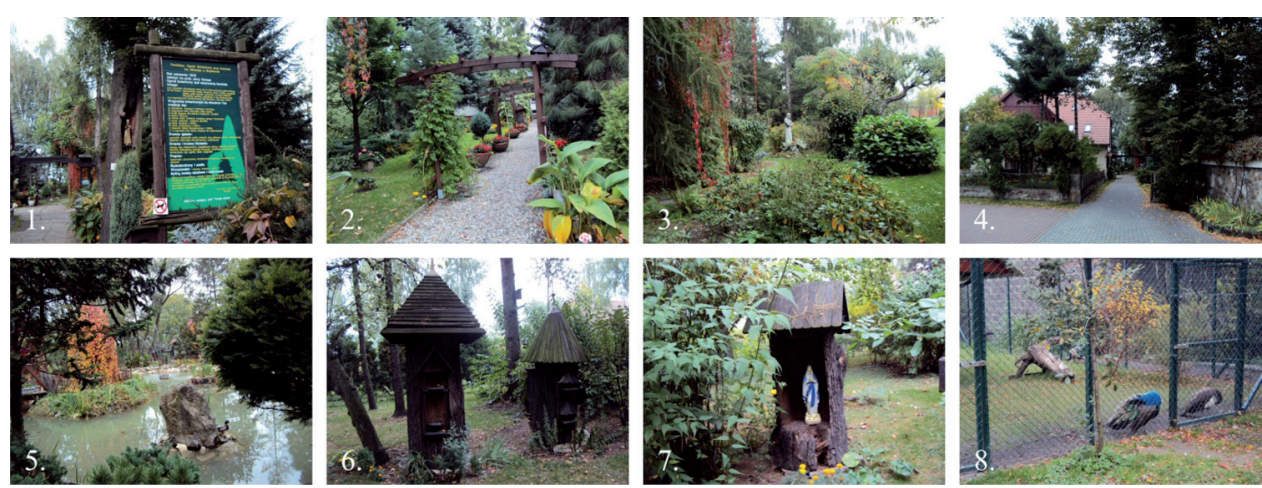

Photo by Magdalena Wilkosz-Mamcarczyk, 2012

Fig. 4. Garden at Bujaków

\section{Conclusions}

In these authors' opinion, parsonage gardens represent a separate category of designed gardens, which hitherto remained undefined. Based on the above research, the authors attempted to define the parsonage gardens as the form greenery that constitutes an element of church gardens. The parsonage gardens are of a mixed - utility and decorative - character, and they typically incorporate areas with auxiliary buildings and utility gardens, including a vegetable garden and an orchard, as well as decorative areas, consisting of a representative garden in front of the parsonage, a decorative garden with numerous elements of small architecture, possibly including a gazebo, a well, and 
some beehives. Often, the garden layouts are supplemented with decorative elements, in the form of statues of saints, small shrines, and crosses. Many parsonage gardens had ponds, formerly used for fish farming, and today merely constituting a decorative element.

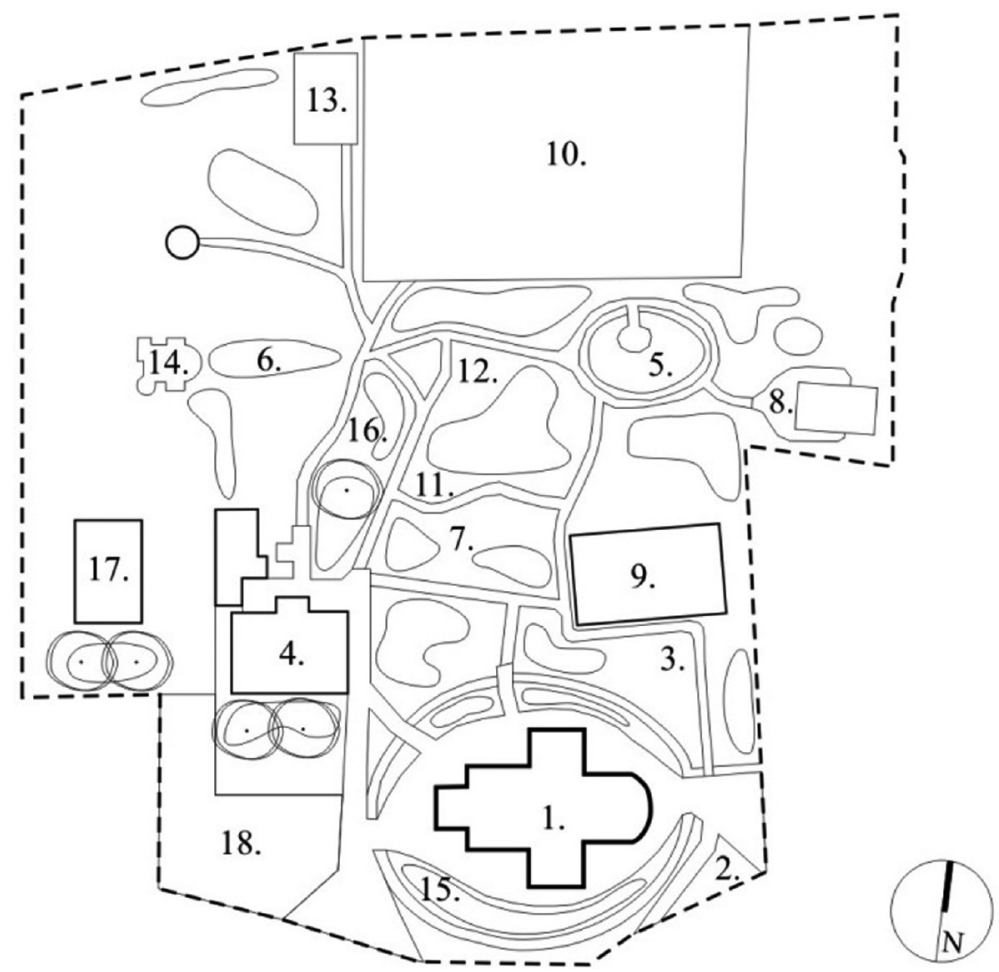

Source: developed on the basis of information contained on the website of the Church of Our Lady in Bujaków (B. Olczak)

Fig. 5. Plan of the garden in Bujaków: 1. Parish Church; 2. Shrine of Saint Adalbert; 3. Penitential Cross from the seventeenth century; 4. Parsonage; 5. Pond with an island; 6. Chapel of Our Lady of the Rosary; 7. Flowers, bushes, trees; 8. Peacocks - visitors' favourite; 9. Catechetical House, convent of the Little Servant Sisters; 10. The house and the garden of priest emeritus; 11. Figure of Merciful Jesus; 12. Beehives and small open-air museum' 13. Herb garden; 14. Field altar' 15. Linden trees surrounding the church - protected, heritage trees; 16. Ancient chestnut; 17. Bonfire pit; 18. Parking lot

Today, parsonage gardens no longer serve their former functions; most of them were converted into meadows around the parsonage building, where festivities, games and meetings are organized. In many cases, some of the land that once belonged to the parsonage has been leased out or sold. The standard of living has also changed, which means there is no need to work on the land or in the orchard. It is regrettable that the designed parsonage gardens have survived in so few places only. Currently, there is 
a tendency for these gardens to disappear (such is the case of Kamień), or to be transformed into decorative and utility gardens (the case of Bujaków). However, mindful of regional traditions and the role that these gardens had played for several centuries, we should absolutely recognize, restore, and promote this type of places [Hodor and Wilkosz-Mamcarczyk 2011].

\section{References}

Apanowicz J. 2002. Metodologia ogólna. Gdynia, 60-77.

Borcz Z., Czechowicz M. 2003. Zieleń towarzysząca obiektom sakralnym. Wrocław, 81-86.

Ciołek G., Bogdanowski J. 1987. Ogrody polskie. Arkady, Warszawa, 18-21.

Hani J. 1994. Symbolika świątyni chrześcijańskiej, Kraków.

Hodor K., Wilkosz-Mamcarczyk M. 2011. Rola strefy sacrum w turystyce pielgrzymkowej na przykładzie wybranych obiektów powiatu wadowickiego oraz krakowskiego. [W:] Turystyka jako rytuał. Red. M.K. Leniartek. Wydawnictwo Wyższej Szkoły Zarządzania „Edukacja”, Wrocław.

Kobielus S. 1997. Człowiek i ogród rajski, Warszawa.

Kucharczyk R. 2002. Ku pamięci przyszłym pokoleniom. Szkice z historii parafii marcyporębskiej. Marcyporęba, maszynopis.

Kucharczyk R. 2013. Z dziejów reformacji na przykładzie parafii marcyporębskiej. Materiały, Świadectwa, Dokumenty, XV(13), Małopolska.

Majdecki L. 2009. Historia ogrodów. T. 1, PWN, Warszawa, 63-82.

Poskrobko B. 2012. Metody badań naukowych z przykładami ich zastosowania. Białystok.

Siewniak M., Mitkowska A. 2998. Tezaurus sztuki ogrodowej. Oficyna Wydawnicza Rytm, Warszawa.

Zinkow J. 2000. Wokół Kalwarii Zebrzydowskiej i Lanckorony. Calvarium, Kalwaria Zebrzydowska, 376-377.

Kronika parafialna z kościoła Św. Marcina w Marcyporębie.

Sanktuarium Matki Bożej w Bujakowie, strona internetowa parafii w Bujakowie. http://www. sw-mikolaj.katowice.opoka.org.pl/kosciol.html

Dr inż. arch. kraj. Magdalena Wilkosz-Mamcarczyk

Uniwersytet Rolniczy w Krakowie

Katedra Gospodarki Przestrzennej i Architektury Krajobrazu

ul. Balicka 253c, 30-198 Kraków

e-mail: magdalena.wilkosz-mamcarczyk@urk.edu.pl

ORCID: 0000-0002-4845-5990

Dr inż. arch. Barbara Olczak

Uniwersytet Rolniczy w Krakowie

Katedra Roślin Ozdobnych i Sztuki Ogrodowej

al. 29 Listopada 54, 31-425 Kraków

e-mail: barbara.olczak@urk.edu.pl

ORCID: 0000-0002-9070-9640 